\title{
Changes in Fetal Lung Distension Alter Expression of Vascular Endothelial Growth Factor and Its Isoforms in Developing Rat Lung
}

\author{
AKIHIKO HARA, CHERYL J. CHAPIN, ROBERT ERTSEY, AND JOSEPH A. KITTERMAN \\ Cardiovascular Research Institute and Departments of Surgery and Pediatrics, University of California,
} San Francisco, California, 94143

\begin{tabular}{|c|c|}
\hline \multicolumn{2}{|c|}{ ABSTRACT } \\
\hline 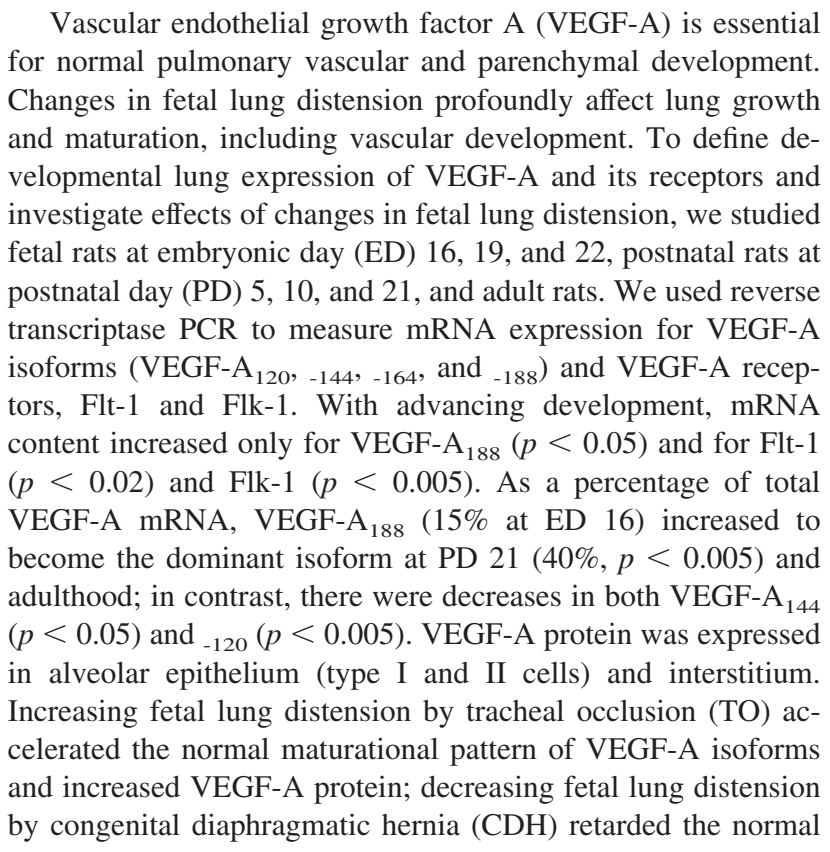 & $\begin{array}{l}\text { developmental pattern and decreased VEGF-A protein. Neither } \\
\text { TO nor CDH consistently affected Flt-1 or Flk-1 mRNA content. } \\
\text { These results show that mechanical factors significantly affect } \\
\text { lung VEGF-A expression and suggest that VEGF-A mediates } \\
\text { previously described changes in lung vascular and parenchymal } \\
\text { development caused by CDH and by TO. (Pediatr Res 58: } \\
\text { 30-37, 2005) } \\
\text { CDHbreviations } \\
\text { ED, embryonic day } \\
\text { NC, nitrofen-exposed control fetuses } \\
\text { PD, postnatal day } \\
\text { rRNA, ribosomal RNA } \\
\text { RTI } \\
\text { membrane } 40 \text { kD protein specific in rat lung to the apical } \\
\text { RTII } \\
\text { membrane } 70 \text { kD protein specific in rat lung to the apical } \\
\text { RT-PCR, reverse transcriptase PCR } \\
\text { TO, tracheal occlusion } \\
\text { VEGF, vascular endothelial growth factor }\end{array}$ \\
\hline
\end{tabular}

Late in gestation, the fetal lung undergoes marked changes in preparation for extrauterine life. These include enlargement of potential airspaces, septal thinning (1), differentiation of the pulmonary epithelium (2), maturation of the surfactant system $(3,4)$, endothelial proliferation, formation of new blood vessels, and alignment of pulmonary capillaries in close proximity to distal airspaces $(5,6)$ to facilitate postnatal gas exchange. These

Received June 30, 2004; accepted November 15, 2004.

Correspondence: Joseph A. Kitterman, M.D., CVRI/Department of Pediatrics, Box 0734, University of California, San Francisco, CA 94143; e-mail: kittermj@ peds.ucsf.edu Supported by Grant HL-24075 from the National Heart, Lung and Blood Institute (NHLBI). A.H. was supported by the Department of Surgery of the Jikei University School of Medicine, Tokyo, Japan.

Current address: Akihiko Hara, M.D., Department of Surgery, The Jikei University School of Medicine, 3-25-8, Nishi-shinbashi, Tokyo 105-8461 Japan.

DOI: 10.1203/01.PDR.0000163614.20031.C5 processes must be tightly regulated by factors that provide mitogenic signals as well as organizational information $(7,8)$.

Formation of the pulmonary vasculature begins at the earliest stages of lung development, continues throughout gestation (6), requires complex interaction among different tissues, and is controlled by spatial and temporal expression of numerous growth factors and their receptors $(9,10)$. Of particular interest is VEGF. The VEGF family consists of five members, VEGF-A, -B, -C, -D, and placental growth factor (reviewed in 11). VEGF-A, the first described and most extensively studied, is involved in angiogenesis, cell proliferation, cell migration, and vascular permeability (11). Deletion of VEGF-A or either of its receptors, Flt-1 and Flk-1 (11), results in embryonic lethality from disruption of vascular development (12-15). In early embryonic life, VEGF-A is expressed widely, but in later gestation is expressed mainly in lung, heart, kidney, vertebral 
column, and brain (16); postnatally, lung has the highest expression (17). VEGF-A mRNA is alternately spliced into at least four isoforms, VEGF-A $A_{188},-164,-144$, and ${ }_{-120}$ in mouse and rat $(18,19)$. Isoform expression varies by tissue and stage of development (20-23). In fetal lung, VEGF-A ${ }_{188}$ expression is low until late gestation, when it increases rapidly to become the dominant isoform just before birth and postnatally. In contrast, VEGF-A $\mathrm{A}_{120}$ and ${ }_{-164}$ are abundantly expressed in mid-gestation; then their expression progressively decreases $(21,23)$.

In prenatal lung, VEGF-A mRNA is expressed in mesenchymal and epithelial cells in mid-gestation, but primarily in epithelial cells in late gestation and postnatally (23-26). VEGF-A affects endothelial cell proliferation and differentiation through its receptors, Flt-1 and Flk-1, located on endothelial cells and their precursors $(6,14,26)$. Recent studies indicate that VEGF-A and its receptors are essential not only for vascular development but also for normal pulmonary parenchymal development, both morphologic $(27,28)$ and functional (29). Both Flt-1 and Flk-1 have been detected recently in distal lung epithelial cells, a finding that supports the role of VEGF as an autocrine as well as paracrine regulator of lung development (30,31).

Fetal lung development is profoundly influenced by mechanical factors, in particular, lung distension. Increased distension (which stretches lung cells), produced by fetal tracheal occlusion, accelerates lung growth and morphologic maturation but retards differentiation of alveolar type 2 cells and surfactant formation (32-35). In contrast, decreased distension retards lung growth and morphologic maturation and favors expression of the type 2 cell phenotype compared with type 1 cells (32,36). A relatively common cause of decreased fetal lung distension, congenital diaphragmatic hernia (CDH), causes pulmonary hypoplasia and abnormal pulmonary vascular development (fewer vessels and increased arteriolar medial musculature) that lead to persistent pulmonary hypertension after birth (37). In experimental animals with $\mathrm{CDH}$, similar vascular abnormalities occur (38-40), and fetal tracheal occlusion reverses some of these abnormalities (41-43).

Mechanical factors also influence VEGF expression in lung tissue. Cyclic mechanical stretch increases expression of VEGF mRNA and protein in cultures of ovine pulmonary vascular smooth muscle cells (44) and in mixed pulmonary cell cultures from fetal and postnatal mouse lungs (45). Previous in vivo studies of $\mathrm{CDH}$ induced by maternal administration of nitrofen have given conflicting results, with $\mathrm{CDH}$ either decreasing VEGF protein $(46,47)$ or increasing VEGF mRNA and protein (48). A concern with some of those studies is that control animals were not exposed to nitrofen, an agent known to alter vascular and parenchymal development in fetal lung $(49,50)$.

As noted above, tracheal occlusion reverses some of the pulmonary vascular abnormalities in $\mathrm{CDH}$ (41-43) and, in vitro, cyclic stretch increases expression of VEGF-A mRNA in pulmonary vascular smooth muscle cells (44) and mixed pulmonary cell cultures (45). Based on those studies, we hypothesized that decreased distension of the fetal lung by $\mathrm{CDH}$ would reduce VEGF-A expression and that increased lung distension by tracheal occlusion would have the opposite effects. As background for the proposed studies, we also defined the expression of VEGF-A, its isoforms and its receptors in developing lung, as these data have not previously been described for the rat.

\section{MATERIALS AND METHODS}

Animals. All studies were approved by the Committee on Animal Research of the University of California, San Francisco, and all procedures conformed with the National Institutes of Health Guide for the Care and Use of Laboratory Animals. Timed pregnant Sprague-Dawley rats (Charles River Laboratories, Hollister, CA) were housed in a laminar flow facility (ambient temperature $21^{\circ} \mathrm{C}$ ) and were provided feed and water ad libitum. We studied 108 fetal rats from 34 pregnant dams, as well as 5 postnatal rats.

Developmental studies. Pregnant dams and their fetuses were anesthetized with maternal intramuscular injections of ketamine (Parke-Davis, Morris Plains, NJ; $180 \mathrm{mg} / \mathrm{kg}$ ) and xylazine (Butler, Columbus, $\mathrm{OH} ; 2.5 \mathrm{mg} / \mathrm{kg}$ ). Thirty minutes after administration of anesthetic, fetuses were delivered by hysterotomy on ED 16, 19, and 22 (term). Each fetus was pithed and weighed; the lungs were dissected free from heart and trachea, weighed, snap frozen in liquid nitrogen and stored at $-80^{\circ} \mathrm{C}$ for future studies. After delivery of all fetuses, dams were euthanized by intracardiac injection of pentobarbital (Euthanasia Solution, Schering-Plough Animal Health Corp., Union, NJ; $1 \mathrm{~mL}$, $390 \mathrm{mg} / \mathrm{mL}$ solution) followed by production of bilateral pneumothoraces. Postnatal animals were anesthetized as described above. Their lungs were removed at PD 5, 10, and 21, and from adult animals.

Tracheal occlusion. On d 20 of gestation (presence of a vaginal plug indicated d 1), dams and fetuses were anesthetized. Through a maternal midline laparotomy, TO was performed on fetuses as previously described (51). Briefly, a section of uterine horn was exposed, a purse string suture (6-0 polypropylene) was placed in the uterus near the fetal head, and the fetal head and neck were exteriorized through a small hysterotomy. Using an operating stereomicroscope, the trachea was exposed and cauterized using a hand-held cautery unit equipped with a microtip. The fetus was returned to the amniotic sac, the purse string suture tightened and the maternal abdomen closed in two layers. With each dam, we performed TO in four fetuses (TO group) and sham operations in two (trachea exposed but not cauterized, Sham group); unoperated littermates were controls (Control group). At ED 22 (term), fetuses were delivered and weighed; their lungs were removed, weighed and frozen as described above. In some fetuses (TO and Control), lungs were prepared for immunohistochemical analysis as described below. In fetuses with TO, lungs were examined for signs of distension (i.e. successful TO); these included large lungs with indentations on the pleural surface from the rib cage, and/or fluid accumulation. Fetuses without distended lungs were excluded from the TO group. After delivery of all fetuses, dams were euthanized as described above.

Congenital diaphragmatic hernia. To produce fetal $\mathrm{CDH}$, timed-pregnant rats (gestation $9.5 \mathrm{~d}$ ) were gavage fed nitrofen (2,4-dichloro-4'-nitrodiphenyl ether, Wako Chemicals, Osaka, Japan), $100 \mathrm{mg}$ dissolved in $1 \mathrm{~mL}$ of olive oil. This produces $\mathrm{CDH}$ in $40-60 \%$ of fetuses (52). In some dams, TO was performed on fetuses at ED 20 as described above. On ED 22, fetuses were delivered, weighed, the abdominal cavity was opened and presence or absence of $\mathrm{CDH}$ was determined by visual inspection of the diaphragm. Lungs were removed, and left and right lungs were separated, weighed, snap frozen, and stored at $-80^{\circ} \mathrm{C}$ for future study. Lungs from these fetuses were separated into three groups: $\mathrm{CDH}$ (fetuses with left-sided $\mathrm{CDH}$ ), nitrofen controls (NC, fetuses exposed to nitrofen that did not have $\mathrm{CDH}$ ), and $\mathrm{CDH}+\mathrm{TO}$ (fetuses with left-sided $\mathrm{CDH}$ and TO).

$\boldsymbol{R N A}$ isolation and $\boldsymbol{R} \boldsymbol{T}-\boldsymbol{P C R}$. Total RNA was isolated from whole lung by the RNAzol method (Tel-Test, Inc., Friendswood, TX) as previously described (36). Multiplex RT-PCR was used for analysis of Flt-1 and Flk-1 mRNA in combination with $18 \mathrm{~S}$ rRNA levels in fetal lung utilizing Competimer technology (Ambion, Austin, TX). Total RNA $(0.125 \mu \mathrm{g})$ was reverse transcribed using random primers. cDNA was amplified with specific oligonucleotide primers for Flt-1 and Flk-1 as previously described (53) and 18S rRNA (QuantumRNA 18S Internal Standards, Ambion). For each gene, we determined the linear range (Flt-1 20 cycles, Flk-1 28 cycles) and the optimal 18S Primer:Competimer ratio (1:9 for Flt-1 and Flk-1). Radiolabeled PCR products were produced using direct incorporation of $\alpha{ }^{32} \mathrm{P}-\mathrm{dCTP}(3000 \mathrm{Ci} / \mathrm{mmol}$, NEN, Boston, MA) during amplification. PCR products were resolved on $6 \%$ polyacrylamide gels containing $8 \mathrm{M}$ urea. After drying the gel, we quantified PCR products using the Storm 840 phosphorimager and ImageQuant software (Molecular Dynamics, Sunnyvale, CA).

Differential splicing of the VEGF-A gene allows for amplification of four isoforms in a single reaction using oligonucleotide primers directed against 
A

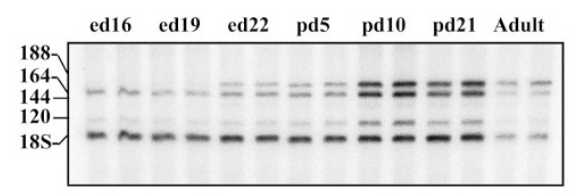

B

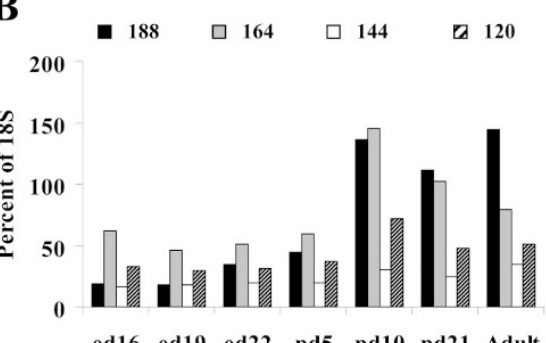

C

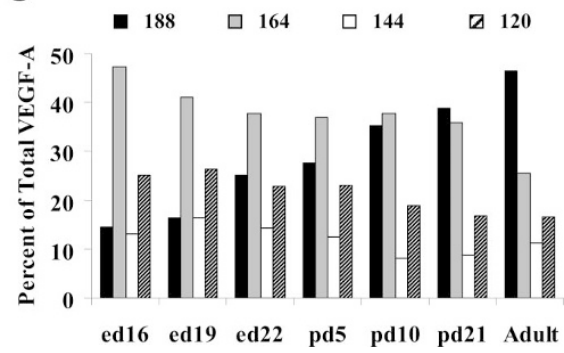

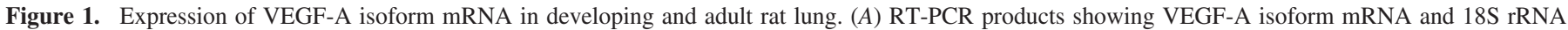

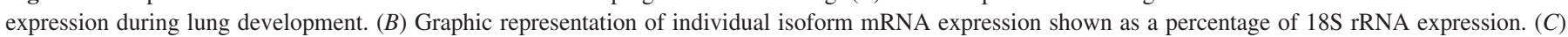

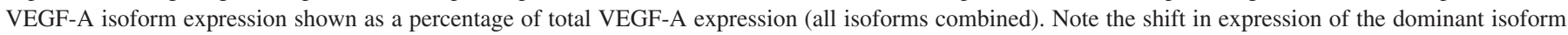
from VEGF-A $A_{164}$ at ED 16 to VEGF-A ${ }_{188}$ in the adult. For each time point, $n=1$. See text for details.

exons 1 and 8 (18). These primers produce PCR products of 564, 492, 432, and 342 base pairs in length corresponding to VEGF-A proteins of 188, 164, 144, and 120 amino acids, respectively $(18,19)$. VEGF-A mRNA isoform expression was quantified by RT-PCR as described above except that $18 \mathrm{~S}$ rRNA levels were determined on the same cDNA sample in a separate tube due to difficulties in multiplexing with these primers. Linear ranges were determined for each and were 20 cycles for all VEGF-A isoforms and 7 cycles for $18 \mathrm{~S}$ rRNA.

$\boldsymbol{V E G F}$-A protein. Whole lungs were homogenized with the aid of a Dounce homogenizer in $1 \mathrm{~mL}$ of $20 \mathrm{mM}$ Tris, $\mathrm{pH} 8.0,137 \mathrm{mM} \mathrm{NaCl}, 1 \%$ Triton X-100, $10 \%$ glycerol containing protease inhibitors (Broad Specificity Protease Inhibitors, Catalogue \#P8340, Sigma Chemical Co., St. Louis, MO). Insoluble material was pelleted by microcentrifugation at $16,000 \mathrm{~g}$ for $30 \mathrm{~s}$ and supernatant was assayed for protein concentration using the bicinchoninic acid modification of the Lowry method (Sigma Chemical Co.) (36). VEGF-A protein levels were determined using the Quantikine M, mouse VEGF Immunoassay kit (R \& D Systems, Minneapolis, MN) according to manufacturer's instructions. This assay recognizes both the 164 and 120 amino acid forms of rat VEGF-A. Serial dilutions $(50,25$, and $12.5 \mu \mathrm{L}$ of supernatant) were assayed in triplicate and values were expressed as picograms VEGF per milligram total lung protein.

Immunohistochemistry. Fetal rat lungs from TO fetuses and littermate Controls were fixed in $4 \%$ paraformaldehyde in situ at a constant intratracheal pressure of $10 \mathrm{~cm} \mathrm{H}_{2} \mathrm{O}$ for $4 \mathrm{~h}$ and processed as previously described (36). Immunohistochemistry was performed on $3-\mu \mathrm{m}$ sections of fixed, cryoprotected rat lung using a primary antibody to VEGF-A. Sections were treated with $1 \% \mathrm{H}_{2} \mathrm{O}_{2}$ for $10 \mathrm{~min}$ at room temperature and washed with $20 \mathrm{mM}$ Tris-buffered $0.9 \% \mathrm{NaCl}, \mathrm{pH} 7.4$ (TBS). Antigen retrieval was performed in 10 mM Na Citrate, pH 6.0 (Target Retrieval Solution, DAKO, Carpinteria, CA) at $95^{\circ} \mathrm{C}$ for $10 \mathrm{~min}$ followed by a cooling phase of $20 \mathrm{~min}$ at room temperature. Sections were washed with TBS and incubated with blocking solution (TBS/ $0.1 \% \mathrm{BSA} / 0.3 \%$ Triton $\mathrm{X}-100 / 10 \%$ rabbit serum) for $1 \mathrm{~h}$ at room temperature to block nonspecific binding. Sections were incubated with $\mathrm{C}-1$ anti-VEGF MAb (Santa Cruz Biotechnology, Santa Cruz, CA), diluted 1:500 in TBS/0.1\% $\mathrm{BSA} / 0.3 \%$ Triton $/ 1.5 \%$ rabbit serum, at $4{ }^{\circ} \mathrm{C}$ overnight. After extensive washing in $\mathrm{TBS} / 0.1 \% \mathrm{BSA} / 0.3 \%$ Triton $\mathrm{X}-100$, sections were incubated with biotin-conjugated rabbit anti-mouse $\mathrm{IgG}$ for $1 \mathrm{~h}$ at room temperature. To control for nonspecific staining, we also processed sections with omission of either the primary antibody or primary and secondary antibodies. To visualize the histochemical localization of VEGF-A, we used the Vectastain ABC Kit (Vector Laboratories, Burlingame, CA) and the DAB (3,3'-diaminobenzidine) Substrate Kit. To label nuclei, sections were counterstained with Gill's No. 2 hematoxylin (Sigma Chemical Co.). Sections were air dried, mounted with Glycergel (DAKO) and analyzed with a Leitz Orthoplan 2 microscope. To identify which pulmonary epithelial cells contained VEGF-A protein, we used serial lung sections either to label VEGF-A or, using double indirect immunofluorescence, to label $\mathrm{RTI}_{40}$ and $\mathrm{RTII}_{70}$, proteins specific in the lung to the apical membranes of rat type I and type II pneumonocytes, respectively; sections were processed as previously described (36).

Statistical analyses. Data for the gestational series were analyzed over time by linear regression. Values for experimental groups (TO, SHAM and Control, or $\mathrm{CDH}, \mathrm{CDH}+\mathrm{TO}$, and $\mathrm{NC}$ ) were compared by ANOVA using Fisher's Protected Least Significant Difference or Bonferroni/Dunn post hoc test where appropriate. Data are presented as percent \pm SD of the relevant control values. All statistical analyses were done using StatView (Abacus Concepts Inc., Berkeley, CA). Statistical significance was assumed for $p$ values $<0.05$.

\section{RESULTS}

Developmental studies. We examined expression of VEGF-A isoforms and their receptors, Flt-1 and Flk-1, in lungs from fetal (ED 16, 19, and 22) and postnatal (PD 5, 10, 21, and adult) rats $(n=1$ for each time point). Levels for each VEGF-A isoform were calculated both as percentage of $18 \mathrm{~S}$ rRNA and as percentage of total VEGF-A message. Relative to 18S, all VEGF-A isoforms were expressed at low levels at ED 16 (Fig. 1A) and increased with development with highest expression after PD 5 (Fig. 1B); thus, total VEGF-A mRNA increased throughout development. For individual isoforms, the increase was significant only for VEGF- $\mathrm{A}_{188}\left(r^{2}=0.721\right.$, $p=0.032$ ). In Figure $1 A$, the bands for VEGF-A $A_{188}$ and ${ }_{-144}$ at ED 16 and 19 are difficult to see; however, clear signals were detected with quantitation by phosphorimager (Fig. $1 B$ ). When calculated as percentage of total VEGF-A mRNA, the isoforms showed different expression patterns (Fig. 1C). VEGF-A $\mathrm{A}_{188}$ was low at ED 16 and then progressively increased through PD $21\left(r^{2}=0.902, p=0.004\right)$ to become equivalent to VEGF$\mathrm{A}_{164}$ at PD 10 and 21 and dominant in adulthood. VEGF-A $\mathrm{A}_{164}$, the dominant form at ED 16, tended to progressively decrease $\left(r^{2}=0.565, p=0.084\right)$ at PD 21 and in adulthood. There were significant decreases from ED 16 to PD 21 for both VEGF$\mathrm{A}_{144}\left(r^{2}=0.661, p=0.049\right)$ and ${ }_{-120}\left(r^{2}=0.900, p=0.004\right)$. Expression patterns of Flt-1 and Flk-1 relative to $18 \mathrm{~S}$ in the same lungs are shown in Figure 2. Flt-1 mRNA expression increased more than 5-fold throughout development $\left(r^{2}=\right.$ $0.792, p=0.017)$ and was maximal in adult lung. Although expressed at lower levels, Flk-1 also increased throughout development $\left(r^{2}=0.890, p=0.004\right)$ but showed only a 2 -fold increase. For all of the above regressions, we excluded the adult values because we were uncertain of the actual age of the adult animal. However, all values are shown in Figures 1 and 2. Analysis of serial lung sections labeled for detection of either VEGF-A or $\mathrm{RTI}_{40}$ and $\mathrm{RTII}_{70}$ showed that VEGF-A protein was present in interstitial cells as well as in both type I and type II pneumonocytes (Fig. 3). No staining was seen with omission of the primary antibodies against VEGF-A, $\mathrm{RTI}_{40}$ and $\mathrm{RTII}_{70}$ (data not shown).

Tracheal occlusion. We studied 36 fetuses from 14 dams. Data were analyzed from three experimental groups: TO $(n=$ 
A $\quad$ ed16 $\quad$ ed19 ed22 pd5 pd10 pd21 Adult
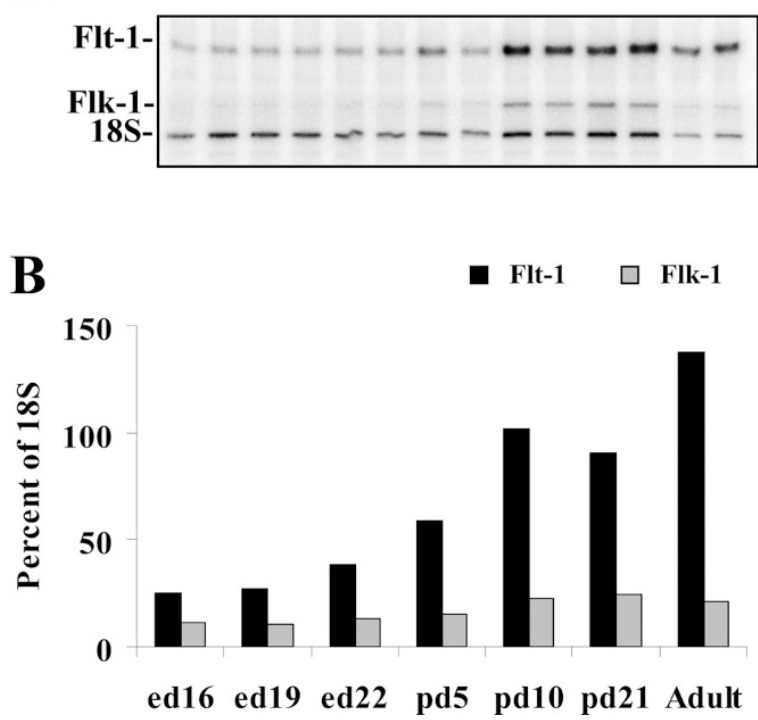

Figure 2. VEGF-A receptor expression in developing and adult lung. $(A)$ RT-PCR products showing Flt-1 and Flk-1 mRNA and 18S rRNA expression during lung development. (B) Graphic representation of VEGF-A receptor expression represented as a percent of $18 \mathrm{~S}$ rRNA. For each time point, $n=1$. Note that expression of both receptors increase over time but the magnitude of increase was greater for Flt-1. See text for details.

10), Sham (sham-operated littermates, $n=11$ ), and Control (unoperated littermates, $n=15$ ). Fetal body weights were similar among the three experimental groups (Table 1). Compared with Sham and Control fetuses, TO significantly increased wet lung weight, both in absolute terms (grams) and as a percentage of body weight (Table 1). These effects were similar among male and female fetuses (data not shown). When calculated as percentages of $18 \mathrm{~S}$ rRNA, all four isoforms of VEGF-A mRNA were significantly increased in lungs of TO fetuses compared with Control fetuses (Fig. 4, $A$ and $B$ ). In addition, TO increased expression of VEGF- $\mathrm{A}_{188}$ and ${ }_{-144}$ in comparison to Sham fetuses. For all isoforms, expression levels did not differ between Sham and Control fetuses. When calculated as percentages of total VEGF-A mRNA and compared with Control and Sham fetuses, TO caused significant
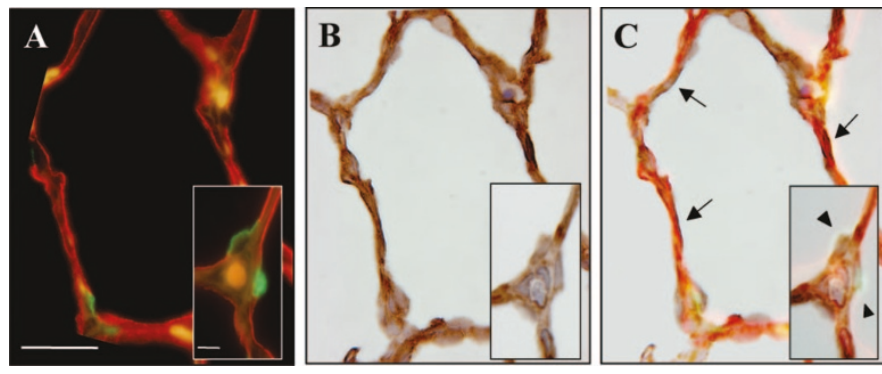

Figure 3. VEGF-A in type I and type II cells in lung of fetal rat at $22 \mathrm{~d}$ gestation. (A) Localization of proteins specific to the apical membranes of alveolar type I cells $\left(\mathrm{RTI}_{40}\right.$, red $)$ and type II cells (inset, $\mathrm{RTII}_{70}$, green). (B) Localization of VEGF-A (brown) in type I cells (dark staining adjacent to apical membrane) and type II cells (inset, diffuse cytoplasmic staining) in a section serial to that in $(A)$. $(C)$ Overlay of $(A)$ and $(B)$. Arrows indicate co-localization of VEGF-A with $\mathrm{RTI}_{40}$ and arrowheads (inset) indicate colocalization of VEGF-A with $\mathrm{RTII}_{70}$. Bar $=25 \mu \mathrm{m}$; inset bar $=5 \mu \mathrm{m}$.
Table 1. Effects of tracheal occlusion and sham operations on body weight and lung weight in fetal rats

\begin{tabular}{lcccc}
\hline \multirow{2}{*}{$\begin{array}{c}\text { Experimental } \\
\text { group }\end{array}$} & & \begin{tabular}{c} 
Body weight \\
\cline { 3 - 5 }$(\mathrm{g})$
\end{tabular} & \multicolumn{2}{c}{ Lung wet weight } \\
\hline Control & 15 & $4.12 \pm 0.36$ & $0.13 \pm 0.02$ & $(\% \mathrm{BW})$ \\
TO & 10 & $4.03 \pm 0.49$ & $0.24 \pm 0.05^{*}$ & $5.83 \pm 0.32$ \\
Sham & 11 & $4.03 \pm 0.48$ & $0.12 \pm 0.01$ & $3.00 \pm 0.32$ \\
\hline
\end{tabular}

Data are mean \pm SD. Experimental group: Control, unoperated littermate; TO, fetus with tracheal occlusion; Sham, littermate fetus with sham operation. $n$, number of fetuses; \% BW, lung weight as a percentage of fetal body weight. There were no significant differences between Control and Sham fetuses for body weights or lung weights. $* p<0.0001 v s$ Control and Sham.

increases in VEGF- $\mathrm{A}_{188}$, significant decreases in VEGF- $\mathrm{A}_{164}$ and ${ }_{-144}$ (compared with Control only), and no change in VEGF- $A_{120}$ expression (Table 2). Using an ELISA that recognizes the 164 and 120 amino acid forms of the protein, we measured VEGF-A in lungs of TO fetuses, Sham fetuses, and littermate controls. TO increased VEGF-A protein levels to $134 \%$ of Control $(p<0.01)$; values did not differ between Control and Sham fetuses (Fig. 4C). In the same lungs, we examined expression of the VEGF-A receptors, Flt-1 and Flk-1. Although TO caused no significant changes in mRNA expression of either receptor, on microscopic examination of the lungs, TO increased the size of the distal potential airspaces (Fig. 5). By immunohistochemistry, VEGF-A appeared increased both in epithelial cells and in interstitial tissue of distal parenchyma in TO fetuses (Fig. 5).

Congenital diaphragmatic hernia. We studied 36 fetuses from 10 dams. Fetuses were divided into three groups: NC (Nitrofen Control, exposed to nitrofen with no $\mathrm{CDH}, n=18$ ), $\mathrm{CDH}$ (left-sided CDH, $n=15$ ), and $\mathrm{CDH}+\mathrm{TO}$ (left-sided $\mathrm{CDH}$ with $\mathrm{TO}, n=3$ ). Because of the small number of $\mathrm{CDH}$ + TO fetuses, the results for that group should be interpreted with caution, and we have not included statistical analyses of the results from that group. Fetal body weights were similar among the three experimental groups (Table 3). CDH significantly decreased lung weight. These effects were similar among male and female fetuses (data not shown). Lung weights from $\mathrm{CDH}+\mathrm{TO}$ fetuses were greater than $\mathrm{NC}$ and $\mathrm{CDH}$ fetuses (when calculated as percentage body weight, Table 3). For the following studies, only the lung ipsilateral to the $\mathrm{CDH}$ (i.e. left lung) was used for analysis. When expressed as a percentage of $18 \mathrm{~S}$ rRNA, none of the mRNA for the four VEGF-A isoforms showed significant differences among the three experimental groups (Fig. 6, $A$ and $B$ ). However, when expressed as a percentage of total VEGF-A mRNA, all isoforms showed significant changes (Table 4). $\mathrm{CDH}$ decreased VEGF-A $_{188}$, increased VEGF-A ${ }_{164}$ and ${ }_{-120}$, and did not affect VEGF- $\mathrm{A}_{144}$ compared with both $\mathrm{NC}$ and $\mathrm{CDH}+\mathrm{TO}$. Furthermore, $\mathrm{CDH}+\mathrm{TO}$ apparently restored expression of VEGF$\mathrm{A}_{188}$ and ${ }_{-164}$ to levels similar to NC, increased VEGF- $\mathrm{A}_{144}$ above $\mathrm{NC}$ and decreased ${ }_{-120}$ to levels below NC. CDH significantly decreased lung content of VEGF-A protein (Fig. $6 C$ ); VEGF-A protein was not assayed in $\mathrm{CDH}+\mathrm{TO}$ fetuses due to the small number of available fetuses. $\mathrm{CDH}$ did not affect expression of mRNA for the VEGF-A receptors, Flt-1 and Flk-1 (data not shown). 

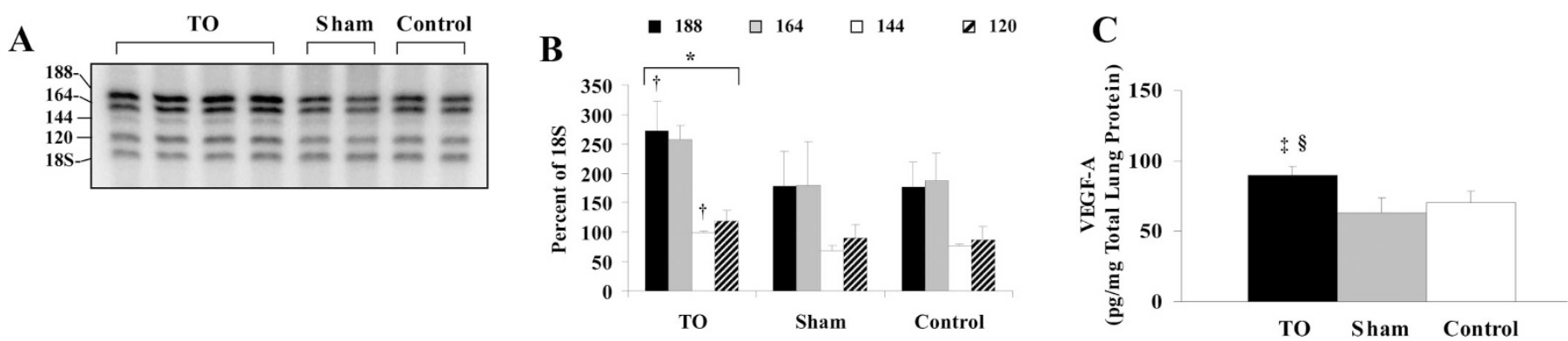

Figure 4. Effects of TO on expression of VEGF-A in fetal rat lungs. (A) Representative phosphor-image showing RT-PCR products of VEGF-A isoform mRNA and 18S rRNA expression in lungs from TO, Sham operated, and Control fetuses at ED 22. (B) Graphic representation of VEGF-A isoform expression in TO $(n=5)$, Sham $(n=4)$, and Control $(n=5)$ lungs expressed as a percentage of $18 \mathrm{~S}$ rRNA levels. Expression levels of all isoforms were increased in lungs with TO compared with Control, and VEGF- $\mathrm{A}_{188}$ and ${ }_{-144}$ were increased compared with Sham. $(C)$ VEGF-A protein levels shown as a percentage of total lung protein in TO $(n=3)$, Sham $(n=5)$, and Control lungs $(n=8)$. TO increased lung VEGF-A protein content. $* p<0.05$ to Control, $\dagger p<0.05$ to Sham, $\ddagger p<0.01$ to Control, § $\mathrm{p}<0.01$ to Sham.

\section{DISCUSSION}

VEGF-A and its receptors are necessary for embryonic survival (12-15) and play essential roles in pulmonary vascular and parenchymal development (27-29,54). In addition, changes in fetal lung distension have marked effects on lung parenchyma $(32-36,51)$ and vasculature $(37,39-43,49)$. We designed the present studies to examine the expression of VEGF-A, its isoforms, and its receptors in developing rat lung and to investigate effects on these critical factors by changes in distension of the fetal lung.

Our results for the developmental pattern of lung expression of the VEGF-A isoforms are similar to those reported previously in baboons (55), mice (23), and rabbits (56). The timing of the postnatal increase in expression in the rat coincides with the period of alveolarization.

The similarity in expression patterns of the VEGF-A isoforms in developing lung across different species is consistent with previous studies showing that normal lung development is dependent upon tight control of the expression of the VEGF-A isoforms both temporally and spatially $(28,54,57)$. The VEGF-A isoforms differ in solubility, heparin binding, receptor affinity, and biologic function $(11,58,59)$. The roles of the various VEGF-A isoforms in lung development have been incompletely defined, but some information is available from studies in transgenic mice. VEGF- $\mathrm{A}_{164}$ and ${ }_{-188}$ are essential for normal vascular and parenchymal development. In the absence of these two isoforms, there is a reduction in the number of airspaces and capillaries (23) and retardation of parenchymal development so that the newborn mice die of respiratory distress due to surfactant deficiency (29). In contrast, with increased expression of VEGF- $\mathrm{A}_{164}$, there is increased vascular development $(28,57)$, a decrease in branching morphogenesis, and decreased type I cell differentiation (28); these effects show variation between distal and central lung areas (54).

In a pattern similar to VEGF-A mRNA, expression of mRNA for the VEGF-A receptors, Flt-1 and Flk-1, increased significantly with advancing gestation and these increases continued after birth (Fig. 2). The progressively increasing expression of the VEGF-A receptors occurs during the period that lung vasculature is undergoing rapid development, findings consistent with previous reports in baboons (55), mice (60), and rats $(9,61)$.

TO was performed to examine effects on VEGF-A of increased distension of the fetal lung. As previously reported $(51,62)$, TO increased fetal lung weight but did not affect fetal body weight (Table 1). TO increased expression of total VEGF-A mRNA and of its four isoforms when normalized to 18S rRNA, (Fig. 4, $A$ and $B$ ). In addition, TO accelerated the normal maturation changes in the relative expression patterns of VEGF-A isoforms (i.e., increase in VEGF- $\mathrm{A}_{188}$ and decrease in VEGF- $\mathrm{A}_{164}$; Table 2). TO also increased the lung concentration of VEGF-A protein (Fig. 4C). Therefore, in addition to being a potent stimulus to lung growth $(32,34,51,52,63)$ and to hastening morphologic maturation of lung parenchyma $(32-34,51,52)$, TO accelerates the maturational patterns of expression of total VEGF-A mRNA and its isoforms that occur in normal fetuses.

Our studies do not provide information as to which cells are responsible for the increased lung expression of VEGF-A with TO. However, based on data from the present studies and previous reports, it seems likely that both vascular and parenchymal tissues are involved. Quinn et al. (44) demonstrated that cyclic stretch increases VEGF-A mRNA in cultures of ovine pulmonary vascular smooth muscle cells, and Muratore and associates (45) reported similar results with cyclic stretch of cultures of mixed pulmonary cells from fetal, neonatal, and adult mice. However, TO causes tonic lung distension, and there is no information available about the in vitro effects on

Table 2. Effects of tracheal occlusion and sham operations on expression of VEGF-A isoform mRNA in lungs of fetal rats

\begin{tabular}{|c|c|c|c|c|}
\hline \multirow{2}{*}{$\begin{array}{l}\text { Experimental } \\
\text { group }\end{array}$} & \multicolumn{4}{|c|}{$\begin{array}{l}\text { VEGF-A isoform mRNA ( } \% \text { of total } \\
\text { VEGF-A mRNA) }\end{array}$} \\
\hline & 188 & 164 & 144 & 120 \\
\hline Control $(n=5)$ & $38 \pm 3$ & $34 \pm 2$ & $12 \pm 0.5$ & $17 \pm 1$ \\
\hline TO $(n=6)$ & $45 \pm 3 \dagger \neq$ & $29 \pm 2 \S \ddagger$ & $9 \pm 0.4 *$ & $16 \pm 1$ \\
\hline Sham $(n=5)$ & $39 \pm 4$ & $33 \pm 3$ & $10 \pm 2$ & $18 \pm 2$ \\
\hline
\end{tabular}

Data are mean \pm SD. Experimental group: Control, unoperated littermate; TO, fetus with tracheal occlusion; Sham, littermate fetus with sham operation. $n$, number of fetuses. * $p<0.0001$ to Control; $\dagger p<0.005$ to Control; $\S p<$ 0.01 to Control; $\$ p<0.05$ to Sham. 
Table 3. Effects of congenital diaphragmatic hernia $(C D H)$ and $\mathrm{CDH}$ with tracheal occlusion on body weight and lung weight in fetal rats

\begin{tabular}{|c|c|c|c|c|}
\hline \multirow{2}{*}{$\begin{array}{c}\text { Experimental } \\
\text { group }\end{array}$} & \multirow[b]{2}{*}{$n$} & \multirow{2}{*}{$\begin{array}{c}\text { Body weight } \\
(\mathrm{g})\end{array}$} & \multicolumn{2}{|c|}{ Lung wet weight } \\
\hline & & & (g) & $(\% \mathrm{BW})$ \\
\hline $\mathrm{CDH}$ & 15 & $4.28 \pm 0.68$ & $0.10 \pm 0.03 \S$ & $2.28 \pm 0.55 \dagger$ \\
\hline $\mathrm{CDH}+\mathrm{TO}$ & 3 & $3.81 \pm 0.66$ & $0.16 \pm 0.02$ & $4.10 \pm 0.17$ \\
\hline $\mathrm{NC}$ & 18 & $4.44 \pm 0.79$ & $0.12 \pm 0.03$ & $2.76 \pm 0.32$ \\
\hline
\end{tabular}

Data are mean \pm SD. Experimental group: $\mathrm{CDH}$, fetus with congenital diaphragmatic hernia; $\mathrm{CDH}+\mathrm{TO}$, fetus with $\mathrm{CDH}$ and tracheal occlusion; $\mathrm{NC}$, nitrofen control (fetus exposed to nitrofen but without $\mathrm{CDH}$ ). $n$, number of fetuses; \% BW, lung weight as a percentage of fetal body weight. There were no significant differences in fetal body weights among the three experimental groups. $\S p<0.02 v s \mathrm{NC} ; \dagger p<0.005 v s \mathrm{NC}$.

VEGF-A expression of tonic stretch of lung cells. Additional studies will be needed to determine whether tonic stretch has effects on VEGF-A expression that are similar to those of cyclic stretch in vitro. Gonzalez et al. (64) recently demonstrated that both alveolar type I and type II cells isolated from rat lung express VEGF-A mRNA. Our immunohistochemical studies show that TO increased VEGF-A protein in distal pulmonary epithelial cells, as well as in interstitial cells (Fig. 5). Specific staining of type I and type II pneumonocytes shows that VEGF-A protein is present in both types of distal pulmonary epithelial cells (Fig. 3). It is of note that Gonzalez and associates (64) reported that the dominant isoform of VEGF-A mRNA is VEGF-A ${ }_{188}$ in type I cells and VEGF-A 120 in type II cells. TO decreases type II cell density $(32,33,35)$ and function $(34,35)$ and stimulates differentiation of pulmonary epithelium into type I cells in fetal rats (51). Therefore, the finding of increased expression of VEGF-A ${ }_{188}$ with $\mathrm{TO}$ in the present study is consistent with type I cells participating in the effects of TO on VEGF-A expression. In contrast to the stimulatory effects on VEGF-A, TO did not significantly influence expression of Flt-1 or Flk-1.

With $\mathrm{CDH}$, the diaphragmatic defect permits herniation of abdominal organs into the thorax, compressing the lungs and decreasing distension of the fetal lung. In our study, this resulted in pulmonary hypoplasia (Table 3 ) but did not affect fetal body weights, findings consistent with the previous report by Kitano et al. (52). In contrast to effects of increased lung distension from $\mathrm{TO}$ as discussed above, $\mathrm{CDH}$ did not affect
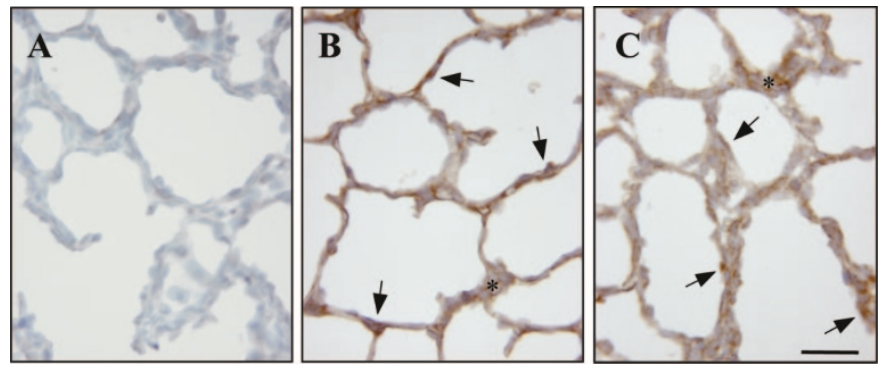

Figure 5. Effects of TO on expression of VEGF-A in distal lung of fetal rats. (A) Lung from TO fetus with omission of the primary antibody. (B) Lung from TO fetus. $(C)$ Lung from littermate control fetus. Note the increased staining for VEGF-A in the TO lung $(B)$ compared with its littermate control $(C)$. There is increased VEGF-A protein in pulmonary epithelial cells (arrows) and interstitial tissue (*). Bar $=50 \mu \mathrm{m}$.

expression of total VEGF-A mRNA nor its isoforms when normalized to $18 \mathrm{~S}$ rRNA (Fig. 6, $A$ and $B$ ). However, $\mathrm{CDH}$ did significantly affect relative expression patterns of VEGF-A isoforms (expressed as percentage of total VEGF-A mRNA); VEGF-A ${ }_{188}$ decreased and VEGF-A ${ }_{164}$ and ${ }_{-120}$ increased (Table 4). These changes due to $\mathrm{CDH}$ are the opposite of both the normal developmental pattern during the last few days of gestation (Fig. 1C) and changes induced by TO (Table 3). Previous reports of the effects of $\mathrm{CDH}$ on VEGF-A expression have yielded conflicting results, and, because of differences in experimental methods, direct comparisons with our results are difficult. Chang et al. (65) reported that with $\mathrm{CDH}$ there was a decrease in the number of fetal lung cells expressing VEGF-A. However, they pooled lungs from nitrofen-exposed fetuses with and without $\mathrm{CDH}$ and compared them to control fetuses not exposed to nitrofen. Nitrofen is known to have potent effects on pulmonary parenchymal and vascular development independent of the presence of $\mathrm{CDH}(49,50)$, including a decrease in VEGF-A expression (66). In contrast, Oue et al. (48) reported that lungs of fetal rats with $\mathrm{CDH}$ had increased expression of VEGF-A $A_{120},-164$, and ${ }_{-188}$ mRNA. These results are similar to ours with regard to relative expressions of VEGF- $_{120}$ and ${ }_{-164}$; however, our study showed a decrease in relative expression of VEGF- $\mathrm{A}_{188}$ and no change in expression of total VEGF-A mRNA. The reasons for these differences are not apparent but may be related to differences in experimental
A

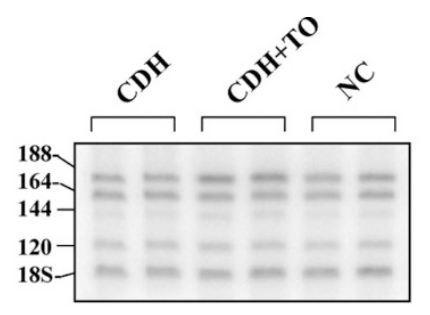

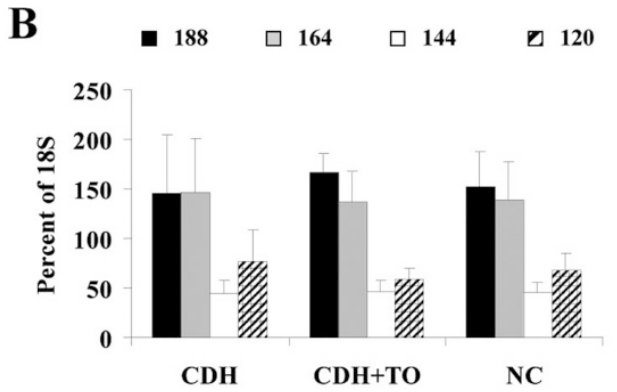

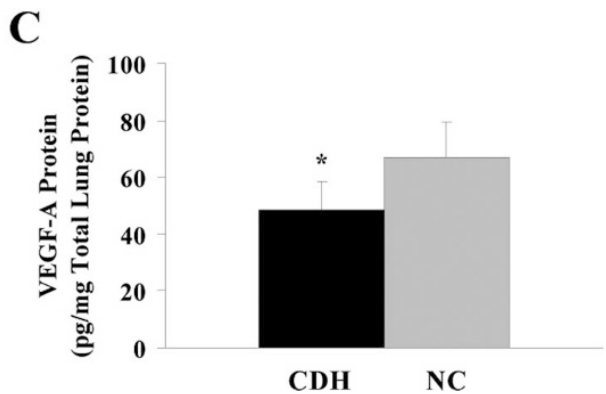

Figure 6. Effects of $\mathrm{CDH}$ and of $\mathrm{CDH}+\mathrm{TO}$ on VEGF-A expression. (A) Representative phosphor-image showing RT-PCR products of VEGF-A isoform mRNA and 18S rRNA expression in lungs from CDH, CDH + TO, and nitrofen-exposed control (NC) fetuses. (B) Graphic representation of VEGF-A isoform expression in the lungs of $\mathrm{CDH}(n=10), \mathrm{CDH}+\mathrm{TO}(n=3)$, and NC fetuses $(n=11)$ at ED 22 shown as a percentage of 18S rRNA expression. None of the isoform levels differed among the three experimental groups. $(C)$ VEGF-A protein levels shown as a percentage of total lung protein in CDH and NC fetuses $(n=5$ for both). CDH significantly decreased VEGF-A protein in fetal lung. $* p<0.005$. 
Table 4. Effects of congenital diaphragmatic hernia $(\mathrm{CDH})$ and of $C D H$ with tracheal occlusion on expression of VEGF-A isoform $m R N A$ in lungs of fetal rats

VEGF-A isoform mRNA (\% of total VEGF-A mRNA)

\begin{tabular}{lllll}
\cline { 2 - 4 } Experimental group & \multicolumn{1}{c}{188} & 164 & 144 & 120 \\
\hline $\mathrm{CDH}(n=10)$ & $34 \pm 2 * \dagger$ & $38 \pm 1 *$ & $10 \pm 2$ & $18 \pm 2 \S$ \\
$\mathrm{CDH}+\mathrm{TO}(n=3)$ & $43 \pm 3$ & $33 \pm 1$ & $11 \pm 1$ & $13 \pm 2$ \\
$\mathrm{NC}(n=12)$ & $40 \pm 3$ & $35 \pm 1$ & $9 \pm 1$ & $16 \pm 2$
\end{tabular}

Data are mean \pm SD. Experimental group: NC, nitrofen control (fetus exposed to nitrofen but without $\mathrm{CDH}) ; \mathrm{CDH}$, fetus with congenital diaphragmatic hernia; $\mathrm{CDH}+\mathrm{TO}$, fetus with $\mathrm{CDH}$ and tracheal occlusion. $n$, number of fetuses. ${ }^{*} p<0.0001$ vs NC; $\$ p<0.05$ vs NC.

methods including selection of control animals, in housekeeping genes, and in cycle numbers for RT-PCR.

Furthermore, consistent with previous reports $(46,47), \mathrm{CDH}$ decreased the amount of VEGF-A protein in the lung (Fig. 6C), an effect opposite that of TO (Fig. 4C). Our results for VEGF-A protein do conflict with those of Shehata et al. (67), who reported increased VEGF in lungs of human infants with $\mathrm{CDH}$ who died after a period of assisted ventilation with high concentrations of oxygen; in that study, VEGF protein was assessed semiquantitatively by immunohistochemistry. The reasons for the differences between their results and our findings are not apparent, but may relate to species differences, changes in VEGF that occurred with birth and as a result of assisted ventilation in the human infants, and the method of assessing VEGF content in the lung (i.e. semiquantitative immunohistochemistry versus quantitative immunoassay).

To determine whether TO could reverse the effects of $\mathrm{CDH}$ on VEGF-A expression, we performed TO in fetuses with $\mathrm{CDH}$. In fetuses with $\mathrm{CDH}$, addition of $\mathrm{TO}$ significantly increased lung weights to greater than those from $\mathrm{CDH}$ fetuses as well as from nitrofen-exposed fetuses without $\mathrm{CDH}$ (Table 3). Additionally, in $\mathrm{CDH}+\mathrm{TO}$ fetuses, there was apparent reversal of the effects of CDH on VEGF-A isoforms so that their relative expression patterns were similar to those in control fetuses (Table 4).

In contrast to effects on VEGF-A mRNA and protein, $\mathrm{CDH}$ did not affect expression of Flt-1 or Flk-1. Our results show that in developing fetal and postnatal rat lung, as in other species $(23,55,56)$, there are clear maturational patterns in the expression of VEGF-A and its isoforms. These maturational patterns are disrupted by changes in distension of the fetal lung. Increased lung distension (by TO) accelerates and decreased lung distension (by $\mathrm{CDH}$ ) retards the normal maturational expression patterns. Furthermore, increased lung distension enhances lung content of VEGF-A protein, and decreased distension has the opposite effect. Thus, mechanical factors, shown previously to affect growth $(32,34,36,62)$, morphologic maturation $(34,35)$, and epithelial differentiation $(33,35,36,51)$ of fetal lung, also markedly influence pulmonary expression of VEGF-A, an angiogenic factor that is critical for normal pulmonary vascular and parenchymal development. Previous studies have shown that TO can reverse some of the pulmonary vascular abnormalities that occur with $\mathrm{CDH}$ (41-43), including decreasing arterial muscularization $(41,42)$ and vascular impedance (43). The present studies suggest that these effects are mediated by changes in VEGF-A expression. Furthermore, because VEGF-A has important nonvascular pulmonary effects $(27,29)$, it is likely that some of the parenchymal effects caused by changes in lung distension are also mediated by VEGF-A. Although our studies do not provide information on the mechanism(s) by which changes in lung distension affect VEGF-A expression, it is reasonable to suggest that other growth factors are involved. Several growth factors up-regulate VEGF-A mRNA expression, including IGF (11); in this regard, increased lung distension in fetal sheep increases lung expression of IGF-I (34) and IGF-II (63).

In summary, changes in distension of the fetal lung have marked effects on expression of VEGF-A and its isoforms, factors that play essential roles in the normal development of pulmonary vasculature and parenchyma. Increased distension accelerates the normal maturational pattern of expression of VEGF-A, whereas decreased lung distension has the opposite effects.

\section{REFERENCES}

1. Burri PH, Moschopulos M 1992 Structural analysis of fetal rat lung development Anat Rec 234:399-418

2. Williams MC, Dobbs LG 1990 Expression of cell-specific markers for alveolar epithelium in fetal rat lung. Am J Respir Cell Mol Biol 2:533-542

3. Ballard PL 1989 Hormonal regulation of pulmonary surfactant. Endocr Rev 10:165181

4. Weaver TE, Whitsett JA 1991 Function and regulation of expression of pulmonary surfactant-associated proteins. Biochem J 273:249-264

5. deMello DE, Sawyer D, Galvin N, Reid LM 1997 Early fetal development of lung vasculature. Am J Respir Cell Mol Biol 16:568-581

6. Schachtner SK, Wang Y, Scott Baldwin H 2000 Qualitative and quantitative analysis of embryonic pulmonary vessel formation. Am J Respir Cell Mol Biol 22:157-165

7. Perl AK, Whitsett JA 1999 Molecular mechanisms controlling lung morphogenesis. Clin Genet 56:14-27

8. Warburton D, Schwarz M, Tefft D, Flores-Delgado G, Anderson KD, Cardoso WV 2000 The molecular basis of lung morphogenesis. Mech Dev 92:55-81

9. Gebb SA, Shannon JM 2000 Tissue interactions mediate early events in pulmonary vasculogenesis. Dev Dyn 217:159-169

10. Stenmark KR, Gebb SA 2003 Lung vascular development: breathing new life into an old problem. Am J Respir Cell Mol Biol 28:133-137

11. Ferrara N, Gerber HP, LeCouter J 2003 The biology of VEGF and its receptors. Nature Med 9:669-676

12. Carmeliet P, Ferreira V, Breier G, Pollefeyt S, Kieckens L, Gertsenstein M, Fahrig M, Vandenhoeck A, Harpal K, Eberhardt C, Declercq C, Pawling J, Moons L, Collen D, Risau W, Nagy A 1996 Abnormal blood vessel development and lethality in embryos lacking a single VEGF allele. Nature 380:435-439

13. Ferrara N, Carver-Moore K, Chen H, Dowd M, Lu L, O'Shea KS, Powell-Braxton L, Hillan KJ, Moore MW 1996 Heterozygous embryonic lethality induced by targeted inactivation of the VEGF gene. Nature 380:439-442

14. Fong GH, Rossant J, Gertsenstein M, Breitman ML 1995 Role of the Flt-1 receptor tyrosine kinase in regulating the assembly of vascular endothelium. Nature 376:66-70

15. Shalaby F, Ho J, Stanford WL, Fischer KD, Schuh AC, Schwartz L, Bernstein A, Rossant J 1997 A requirement for Flk-1 in primitive and definitive hematopoiesis and vasculogenesis. Cell 89:981-990

16. Jakeman LB, Armanini M, Phillips HS, Ferrara N 1993 Developmental expression of binding sites and messenger ribonucleic acid for vascular endothelial growth factor suggests a role for this protein in vasculogenesis and angiogenesis. Endocrinology 133:848-859

17. Monacci WT, Merrill MJ, Oldfield EH 1993 Expression of vascular permeability factor/vascular endothelial growth factor in normal rat tissues. Am J Physiol 264:C995-C1002

18. Burchardt M, Burchardt T, Chen MW, Shabsigh A, de la Taille A, Buttyan R, Shabsigh R 1999 Expression of messenger ribonucleic acid splice variants for vascular endothelial growth factor in the penis of adult rats and humans. Biol Reprod 60:398-404

19. Shima DT, Kuroki M, Deutsch U, Ng YS, Adamis AP, D'Amore PA 1996 The mouse gene for vascular endothelial growth factor. Genomic structure, definition of the transcriptional unit, and characterization of transcriptional and post-transcriptional regulatory sequences. J Biol Chem 271:3877-3883

20. Bacic M, Edwards NA, Merrill MG 1995 Differential expression of vascular endothelial growth factor (vascular permeability factor) forms in rat tissues. Growth Factors 12:11-15

21. Greenberg JM, Thompson FY, Brooks SK, Shannon JM, McCormick-Shannon K, Cameron JE, Mallory BP, Akeson AL 2002 Mesenchymal expression of vascular 
endothelial growth factors D and A defines vascular patterning in developing lung. Dev Dyn 224:144-153

22. Ishii H, Oota I, Arakawa T, Takuma T 2002 Differential gene expression of vascular endothelial growth factor isoforms and their receptors in the development of the rat masseter muscle. Arch Oral Biol 47:505-510

23. Ng YS, Rohan R, Sunday ME, deMello DE, D'Amore PA 2001 Differential expression of VEGF isoforms in mouse during development and in the adult. Dev Dyn 220:112-121

24. Berse B, Brown LF, Van de Water L, Dvorak HF, Senger DR 1992 Vascula permeability factor (vascular endothelial growth factor) gene is expressed differentially in normal tissues, macrophages and tumors. Mol Biol Cell 3:211-220

25. Fehrenbach H, Kaspar M, Haase M, Schuh D, Muller M 1999 Differential immunolocalization of VEGF in rat and human adult lung, and in experimental rat lung fibrosis: light, fluorescence, and electron microscopy. Anat Rec 254:61-73

26. Dumont DJ, Fong GH, Puri MC, Gradwohl G, Alitalo K, Breitman ML 1995 Vascularization of the mouse embryo: a study of $f k-1$, tek, and tie, and vascular endothelial growth factor expression during development. Dev Dyn 203:80-92

27. Jakkula M, Le Cras TD, Gebb S, Hirth KP, Tuder RM, Voelkel NF, Abman SH 2000 Inhibition of angiogenesis decreases alveolarization in the developing rat lung. Am J Physiol Lung Cell Mol Physiol 279:L600-L607

28. Zeng X, Wert SE, Federici R, Peters KG, Whitsett JA 1998 VEGF enhances pulmonary vasculogenesis and disrupts lung morphogenesis in vivo. Dev Dyn 211:215-227

29. Compernolle V, Brusselmans K, Acker T, Hoet P, Tjwa M, Beck H, Plaisance S, Dor Y, Keshet E, Lupu F, Nemery B, Dewerchin M, Van Veldhoven P, Plate K, Moon L, Collen D, Carmeliet P 2002 Loss of HIF-2 $\alpha$ and inhibition of VEGF impair fetal lung maturation, whereas treatment with VEGF prevents fatal respiratory distress in premature mice. Nat Med 8:702-710

30. Brown KR, England KM, Goss KI, Snyder JM, Acarregui MJ 2001 VEGF induces airway epithelial cell proliferation in human fetal lung in vitro. Am J Physiol Lung Cell Mol Physiol 281:L1001-L1010

31. Lassus P, Turanlahti M, Heikkila P, Andersson LC, Nupponen I, Sarnesto A Andersson S 2001 Pulmonary vascular endothelial growth factor and Flt-1 in fetuses, in acute and chronic lung disease, and in persistent pulmonary hypertension of the newborn. Am J Resp Crit Care Med 164:1981-1987

32. Alcorn D, Adamson TM, Lambert TF, Maloney JE, Ritchie BC, Robinson PM 1977 Morphological effects of chronic tracheal ligation and drainage in the fetal lamb lung. J Anat 123:649-660

33. Flecknoe S, Harding R, Maritz G, Hooper SB 2000 Increased lung expansion alter the proportions of type I and type II alveolar epithelial cells in fetal sheep. Am J Physiol Lung Cell Mol Physiol 278:L1180-L1185

34. Joe P, Wallen LD, Chapin CJ, Lee CH, Allen L, Han VK, Dobbs LG, Hawgood S, Kitterman JA 1997 Effects of mechanical factors on growth and maturation of the lung in fetal sheep. Am J Physiol Lung Cell Mol Physiol 272:L95-L105

35. Piedboeuf B, Laberge JM, Ghitulescu G, Gamache M, Petrov P, Belanger S, Chen MF, Hashim E, Possmayer F 1997 Deleterious effect of tracheal obstruction on type II pneumocytes in fetal sheep. Pediatr Res 41:473-479

36. Kitterman JA, Chapin CJ, Vanderbilt JN, Porta NF, Scavo LM, Dobbs LG, Ertsey R, Goerke J 2002 Effects of oligohydramnios on lung growth and maturation in the fetal rat. Am J Physiol Lung Cell Mol Physiol 282:L431-L439

37. Levin DL 1978 Morphologic analysis of the pulmonary vascular bed in congenital left-sided diaphragmatic hernia. J Pediatr 92:805-809

38. Difiore JW, Fauza DO, Slavin R, Wilson JM 1995 Experimental fetal tracheal ligation and congenital diaphragmatic hernia: a pulmonary vascular morphometric analysis. J Pediatr Surg 30:917-924

39. Hill AC, Adzick NS, Stevens MB, Mori H, Husseini W, Heymann MA 1994 Fetal lamb pulmonary hypoplasia: pulmonary vascular and myocardial abnormalities. Ann Thorac Surg 57:946-951

40. Tenbrinck R, Gaillard JLJ, Tibboel D, Kluth D, Lachmann B, Molenaar JC 1992 Pulmonary vascular abnormalities in experimentally induced congenital diaphragmatic hernia in rats. J Pediatr Surg 27:862-865

41. Kanai M, Kitano Y, von Allmen D, Davies P, Adzick NS, Flake AW 2001 Fetal tracheal occlusion in the rat model of nitrofen-induced congenital diaphragmatic hernia: tracheal occlusion reverses the arterial structural abnormality. J Pediatr Surg 36:839-845

42. Luks FI, Wild YK, Piasecki GJ, De Paepe ME 2000 Short-term tracheal occlusion corrects pulmonary vascular anomalies in the fetal lamb with diaphragmatic hernia. Surgery 128:266-272

43. Sylvester KG, Rasanen J, Kitano Y, Flake AW, Crombleholme TM, Adzick NS 1998 Tracheal occlusion reverses the high impedance to flow in the fetal pulmonary circulation and normalizes its physiological response to oxygen at full term. J Pediatr Surg 33:1071-1075
44. Quinn TP, Schlueter M, Soifer SJ, Gutierrez JA 2002 Cyclic mechanical stretch induces VEGF and FGF-2 expression in pulmonary vascular smooth muscle cells. Am J Physiol Lung Cell Mol Physiol 282:L897-L903

45. Muratore CS, Nguyen HT, Ziegler MM, Wilson JM 2000 Stretch-induced upregulation of VEGF gene expression in murine pulmonary culture: a role for angiogenesis in lung development. J Pediatr Surg 35:906-913

46. Chinoy MR, Graybill MM, Miller SA, Lang CM, Kauffman GL 2002 Angiopoietin-1 and VEGF in vascular development and angiogenesis in hypoplastic lungs. Am J Physiol Lung Cell Mol Physiol 283:L60-L66

47. Okazaki T, Sharma HS, Aikawa M, Yamataka A, Nagai R, Miyano T, Tibboel D 1997 Pulmonary expression of vascular endothelial growth factor and myosin isoforms in rats with congenital diaphragmatic hernia. J Pediatr Surg 32:391-394

48. Oue T, Yoneda A, Shima H, Taira Y, Puri P 2002 Increased vascular endothelial growth factor peptide and gene expression in hypoplastic lung in nitrofen induced congenital diaphragmatic hernia in rats. Pediatr Surg Int 18:221-226

49. Coleman C, Zhao J, Gupta M, Buckley S, Tefft JD, Wuenschell CW, Minoo P, Anderson KD, Warburton D 1998 Inhibition of vascular and epithelial differentiation in murine nitrofen-induced diaphragmatic hernia. Am J Physiol Lung Cell Mol Physiol 274:L636-L646

50. Guilbert TW, Gebb SA, JM Shannon 2000 Lung hypoplasia in the nitrofen model of congenital diaphragmatic hernia occurs early in development. Am J Physiol Lung Cell Mol Physiol 279:L1159-L1171

51. Yoshizawa J, Chapin CJ, Sbragia L, Ertsey R, Gutierrez JA, Albanese CT, Kitterman JA 2003 Tracheal occlusion stimulates cell cycle progression and type I cell differentiation in lungs of fetal rats. Am J Physiol Lung Cell Mol Physiol 285:L344-L353

52. Kitano Y, Davies P, von Allmen D, Adzick NS, Flake AW 1999 Fetal tracheal occlusion in the rat model of nitrofen-induced congenital diaphragmatic hernia. J Appl Physiol 87:769-775

53. Sato T, El-Assal ON, Ono T, Yamanoi A, Dhar DK, Nagasue N 2001 Sinusoidal endothelial cell proliferation and expression of angiopoietin/Tie family in regenerating rat liver. J Hepatol 34:690-698

54. Akeson AL, Greenberg JM, Cameron JE, Thompson FY, Brooks SK, Wiginton D, Whitsett JA 2003 Temporal and spatial regulation of VEGF-A controls vascular patterning in the embryonic lung. Dev Biol 264:443-455

55. Maniscalco WM, Watkins RH, Pryhuber GS, Bhatt A, Shea C, Huyck H 2002 Angiogenic factors and alveolar vasculature: development and alterations by injury in very premature baboons. Am J Physiol Lung Cell Mol Physiol 282:L811-L823

56. Watkins RH, D'Angio CT, Ryan RM, Patel A, Maniscalco WM 1999 Differential expression of VEGF mRNA splice variants in newborn and adult hyperoxic lung injury. Am J Physiol Lung Cell Mol Physiol 276:L858-L867

57. Ruhrberg C, Gerhardt H, Golding M, Watson R, Ioannidou S, Fujisawa H, Betsholtz C, Shima D 2002 Spatially restricted patterning cues provided by heparin-binding VEGF-A control blood vessel branching morphogenesis. Genes Dev 16:2684-2698

58. Neufeld G, Cohen T, Gengrinovitch S, Poltorak Z 1999 Vascular endothelial growth factor (VEGF) and its receptors. FASEB J 13:9-22

59. Stalmans I, Ng YS, Rohan R, Fruttiger M, Bouche A, Yuce A, Fujisawa H, Hermans B, Shani M, Jansen S, Hicklin D, Anderson DJ, Gardiner T, Hammes HP, Moon L, Dewerchin M, Collen D, Carmeliet P, D'Amore PA 2002 Arteriolar and venular patterning in retinas of mice selectively expressing VEGF isoforms. J Clin Invest 109:327-336

60. Bhatt AJ, Amin SB, Chess PR, Watkins RH, Maniscalco WM 2000 Expression of vascular endothelial growth factor and Flk-1 in developing and glucocorticoid-treated mouse lung. Pediatr Res 47:606-613

61. Hosford GE, Olson DM 2003 Effects of hyperoxia on VEGF, its receptors, and HIF- $2 \alpha$ in the newborn rat lung. Am J Physiol Lung Cell Mol Physiol 285:L161L168

62. Kitano Y, Yang EY, von Allmen D, Quinn TM, Adzick NS, Flake AW 1998 Tracheal occlusion in the fetal rat: a new experimental model for the study of accelerated lung growth. J Pediatr Surg 33:1741-1744

63. Hooper SB, Han VK, Harding R 1993 Changes in lung expansion alter pulmonary DNA synthesis and IGF-II expression in fetal sheep. Am J Physiol 265:L403-L409

64. Gonzalez RF, Ertsey R, Dobbs LG 2003 Expression of VEGF isoforms in rat alveolar type I and type II cells. Mol Biol Cell 14(suppl):118a

65. Chang R, Andreoli S, Ng YS, Truong T, Smith SR, Wilson J, D'Amore PA 2004 VEGF expression is downregulated in nitrofen-induced congenital diaphragmatic hernia. J Pediatr Surg 39:825-828

66. Chapin CJ, Hara A, Ertsey R, Kitterman JA 2004 Nitrofen exposure, in the absence of diaphragmatic hernia, differentially affects expression of epithelial and vascular developmental markers in fetal rat lung. Pediatr Res 55:451A

67. Shehata SM, Mooi WJ, Okazaki T, El-Banna I, Sharma HS, Tibboel D 1999 Enhanced expression of vascular endothelial growth factor in lungs of newborn infants with congenital diaphragmatic hernia and pulmonary hypertension. Thorax $54: 427-431$ 